\title{
Can nearby eutrophic reservoirs sustain a differentiated biodiversity of planktonic microcrustaceans in a tropical semiarid basin?
}

\author{
LEIDIANE P. DINIZ and MAURO DE MELO-JÚNIOR \\ Laboratório de Ecologia do Plâncton, Departamento de Biologia, Universidade Federal Rural de Pernambuco/ \\ UFRPE, Rua Dom Manoel de Medeiros, s/n, Dois Irmãos, 52171-900 Recife, PE, Brazil
}

Manuscript received on June 23, 2017; accepted for publication on September 1, 2017

\begin{abstract}
This paper aims to compare alpha and beta diversities of planktonic microcrustaceans from three reservoirs located nearby in a tropical semiarid basin. Our hypothesis was that alpha and beta diversities of the community are different, although the ecosystems are located close to each other. We carried out two sampling campaigns: dry and rainy seasons. The sampling of microcrustaceans and environmental variables (dissolved oxygen, chlorophyll $a$ and nutrient) was performed at twelve stations and were distributed throughout the three zones (river, transition, and lacustrine), using a plankton net $(45 \mu \mathrm{m})$. The reservoirs showed different uses and types of nitrogen predominance: Cachoeira (supply/nitrate), Borborema (sewage/ammonia) and Saco (aquaculture/ammonia). Seventeen species were recorded whose richness was assessed as particularly specific to each one of the studied reservoirs. Seasonally, both reservoirs with high anthropogenic alteration showed greater richness in the dry season. The three reservoirs located in a same basin showed different richness and composition, but the diversity did not differ between the zones of the reservoirs. Although communities are close to each other, their composition and richness were found to be distinct for each reservoir. This may be in response to the peculiar particularities, such as nitrogen sources and the different uses.
\end{abstract}

Key words: alpha and beta diversities, artificial lakes, Cladocera, Copepoda, Brazil, zooplankton.

\section{INTRODUCTION}

Reservoirs are considered transitional ecosystems between lentic and lotic environments (Straškraba and Tundisi 1999), and they are of great importance regarding their economical, social and ecological attributes. Unfortunately, the biodiversity of these aquatic ecosystems is threatened, mainly due to their susceptibility to eutrophication caused by

Correspondence to: Leidiane Pereira Diniz

E-mail: leidianeediniz@gmail.com excess nutrients from industrial and domestic sewage, in addition to surface runoff from agrotoxic rich waters from agriculture (Yang et al. 2008) and aquaculture systems (Arruda et al. 2017). Eutrophication processes in the reservoirs may result in functional losses, making the species composition more homogeneous despite greater niche overlap (Costa et al. 2016).

Zooplankton is an important component of continental aquatic ecosystems, especially the microcrustaceans within the community Cladocera 
and Copepoda. Due their short life cycle and high reproductive efficiency, these invertebrates respond rapidly to physico-chemical changes in water (Gazonato-Neto et al. 2014). Thus, their life history and their patterns of richness and composition depend of various environmental characteristics.

Currently, 620 species of cladocerans have been listed worldwide (Forró et al. 2008). Among them, 120 species occur in Brazilian waters (Elmoor-Loureiro 2000), of which 55 were catalogued for Pernambuco State, a Central State in Northeastern Brazil (Soares and Elmoor-Loureiro 2011, Diniz et al. 2013, Sousa et al. 2015a, b). Among the freshwater copepods, more than 2000 species have been described all around the world. In the Neotropical region, 148 species of the order Cyclopoida and 82 species of the order Calanoida (family Diaptomidae) were registered (Boxshall and Defaye 2008, Silva 2008). Although there is high biodiversity in aquatic environments, the species number may be much larger.

The species diversity varies greatly within the aquatic systems, depending on a complex range of physical, chemical and biological factors (Wetzel 1993). Consequently, species that have a variety of ecological requirements occur in different locations, which results in increased beta diversity (Lopes et al. 2014). As a matter of fact, most studies considered only the number of species in one location (alpha diversity) in order to determine the diversity. However, understanding the variation in composition along an environmental gradient or between reservoirs (beta diversity) is of great importance for ecological interpretations and for conservation measures (Melo et al. 2011).

According to the neutral theory of biodiversity (Hubbell 2001), diversity tends to increase with the distance between habitat patches. Studying beta diversity in tropical lakes, Lopes et al. (2014) observed that connectivity between systems is tendency to homogenize richness. Havel et al. (2002) also observed that the dispersion of a cladoceran species, for example, was restricted to a distance of $20 \mathrm{~km}$. Thus, reservoirs that are not connected but are close to each other can show a similar aquatic biota, if their physical and chemical variables are similar.

However, the different sources of pollution and the deterioration of water quality can lead to a differentiated composition of the community (Burford and Pearson 1998, Hunt and Matveev 2005, Bozelli et al. 2009), even in systems located close to each other. And, this can be used as a tool to indicate the environment condition and help in management. Therefore, the present study aimed to compare the alpha and beta diversities of planktonic cladocerans and copepods in three eutrophic reservoirs from the Neotropical semiarid region (Pernambuco, Brazil). Our hypothesis is that due to the different uses and alterations, which suggest a differentiated predominance of nutrients, the alpha and beta diversities of the planktonic microcrustaceans are different, although all them are eutrophic and located close to each other $(<3$ $\mathrm{km})$ and in a same basin (Pajeú river).

\section{MATERIALS AND METHODS}

\section{STUDY AREA}

The study was carried out in three reservoirs of a Neotropical semiarid basin (Pajeú river), in the town of Serra Talhada, Pernambuco State, Northeastern Brazil: an aquaculture-use reservoir (Saco I) $\left(07^{\circ} 59^{\prime} 31^{\prime}\right.$ S $\left.038^{\circ} 17^{\prime} 5^{\prime} \mathrm{W}\right)$, a sewage discharge reservoir (Borborema) (07 $58^{\prime} 41^{\prime \prime S}$ $\left.038^{\circ} 17^{\prime} 59^{\prime \prime} \mathrm{W}\right)$ and a water supply reservoir (Cachoeira II) (0756’35”S 038 20’07’W) (Table I) (Fig. 1).

The reservoirs have distinct characteristics according to their different uses: (i) Saco I has a capacity of $36,000.000 \mathrm{~m}^{3}$ (APAC 2016) and is hypereutrophic (Almeida et al. 2009). The aquaculture activity was established to raise fish in either net tanks or cages fish farms in 2004 (Arruda 


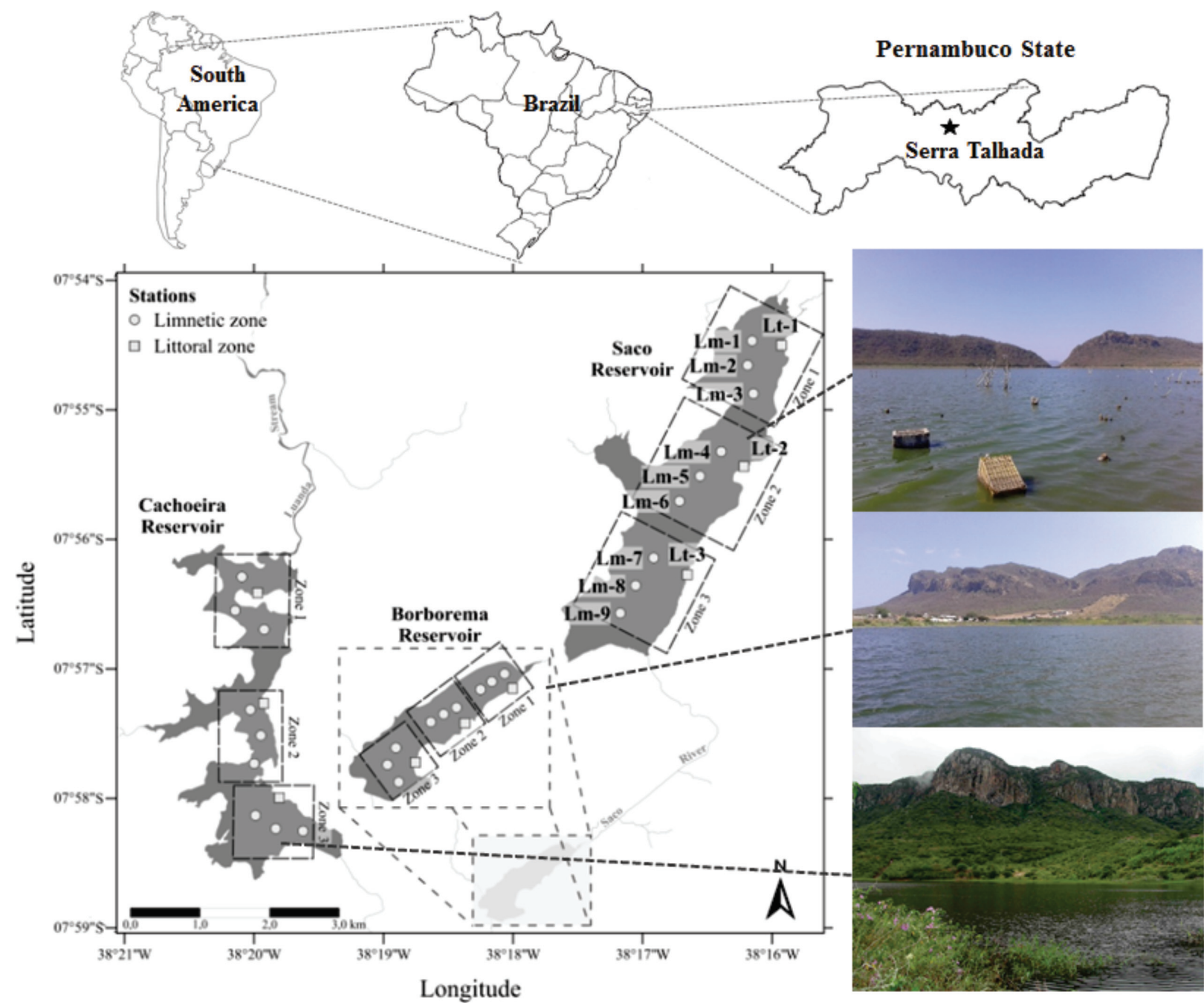

Figure 1 - Study area and sample design showing the distribution of the sampling points in the three reservoirs in a tropical semiarid basin (Pajeú river).

et al. 2017). However, even before the introduction of these aquaculture systems this source had already been considered as hypereutrophic since 1998 (Bouvy et al. 2001). Throughout the study no aquatic macrophytes were recorded in this reservoir. Nevertheless, in the rainy season there was a bloom of the cyanobacteria Cylindrospermopsis raciborskii (Woloszynska) Seenayya \& Subba Raju (M.C.P. Vilar, personal communication). The water in this reservoir is dark green; (ii) Borborema reservoir, which is also considered eutrophic, is located near the federal highway, hence receiving greater anthropic influence. The macrophytes
Poaceae (undetermined sp.) and Eichhornia crassipes (Mart.) Solms were recorded in the transition and lacustrine zones of the reservoir, respectively. The water in this reservoir is light green; and (iii) Cachoeira II reservoir has a capacity of 21,031.145 $\mathrm{m}^{3}$ (APAC 2016), which is mainly formed by Cachoeira stream and is also used to supply the city. The river zone (zone 1) of this reservoir presented an extensive bank of aquatic macrophytes: Salvinia auriculata Aubl., Azolla sp. and Ludwigia helminthorrhiza Mart. The water in this reservoir is transparent. 


\section{ENVIRONMENTAL DESCRIPTORS}

To determine the usage and conservation state of each reservoir, the Rapid Environmental Assessment Protocol was adapted for each one of the reservoirs (Brito et al. 2016). Each environment was characterized by its dissolved oxygen, chlorophyll $a$ and nutrient content analyses (phosphorus, nitrite, nitrate, total nitrogen and ammonia). The dissolved oxygen was measured by mean a multiparameter probe, Horiba U-52. The analysis of chlorophyll $a$ was performed with subsurface water samples, which had a volume of $\sim 500 \mathrm{~mL}$. The samples were filtered through the cellulose membrane GF/F filters $(0.45 \mu \mathrm{m}$ membrane size and with a diameter of $47 \mathrm{~mm}$ ). Subsequently, the concentration of chlorophyll $a$ was determined using hot ethanol as the solvent (Chorus and Bartram 1999).

The water samples were collected in $500 \mathrm{~mL}$ containers, and they were frozen until analysis. Nitrite and nitrate concentration (Mackereth et al. 1978), total phosphorus (Strickland and Parsons 1960) and ammonia (Koroleff 1976), were determined. The total nitrogen was obtained from the sum of nitrite, nitrate and ammonia.

To determine the trophic state of the reservoir, considering the values of chlorophyll $a$ and phosphorus, the Carlson's (1977) index modified by Toledo Júnior (1990) indicates the following status for reservoirs: ultra-oligotrophic $(\leq 24)$, oligotrophic $(24<$ IET $\leq 44)$, mesotrophic $(44<$ IET < 54), eutrophic $(54<$ IET < 74) and hypereutrophic (IET $>74)$.

Because the reservoirs are located in an extremely dry area, the mean monthly precipitation was calculated considering a historical data collection of the last 10 years obtained from APAC (2016). This was to verify the rainfall distribution in the region between the dry and rainy seasons throughout the study period.

\section{DATA COLLECTION}

The collections were carried out twice in each of the reservoirs, always in the morning: the first between August and September/2015 (dry season), and the second in March/2016 (rainy season).

We selected 12 stations (9 limnetic and 3 littoral), distributed in three zones throughout the reservoirs (Fig. 1): (i) river zone, (ii) transition zone, and (iii) lacustrine zone, totalizing 72 samples. At each collection point, $100 \mathrm{~L}$ of water was sampled at the subsurface with the aid of a graduated container, and passed through a plankton net with $45 \mu \mathrm{m}$ mesh size. The organisms were fixed with $4 \%$ neutral formalin.

In the laboratory, the organisms were identified under optical microscope and stereomicroscope using specific bibliography (e.g., Reid 1985, Matsumura-Tundisi 1986, Elmoor-Loureiro 1997, Perbiche-Neves et al. 2015). For each sample, were realized three 2-mL replicates into SedgwickRafter-type chamber, prepared specifically for this volume. The samples with a low number of organisms ( $\mathrm{n}=<150-200$ microcrustaceans) were analysed in full.

\section{DATA ANALYSIS}

The species data were first analysed according to the alpha diversity and the frequency of occurrence. To compare the richness of the three reservoirs, rarefaction curves were plotted, based on the abundance of the microcrustaceans. The curve was performed in the R software, using the vegan package (R Development Core Team 2015). In order to verify the possible differences in alpha diversity of microcrustaceans between the seasons (dry and rainy), the non-parametric Mann-Whitney test was used. Data normality was tested using the D'Agostino test. Because the residual normality of the data was not reached, the Kruskal-Wallis test was used to verify the possible differences in the richness of microcrustaceans among the three 
zones of the reservoirs. The level of significance was $p<0.05$. For these statistical analyzes, Bioestat 5.3 was used.

To verify whether the beta diversity of planktonic cladocerans and copepods was different between the reservoirs, the multivariate permutation analysis of variance using distance matrices was used (PERMANOVA, "Adonis" function in program R, see Oksanen et al. 2016) as well as the Non-Metric Multidimensional Scaling (NMDS) with dissimilarity matrix calculated from the Jaccard method. In addition, to verify which species contributed to the similarity between each one of the reservoirs, the SIMPER analysis (percentage of similarity) was used.

\section{RESULTS}

\section{ENVIRONMENTAL DESCRIPTORS}

According to the Rapid Environmental Assessment Protocol, which was adapted for the reservoirs, Borborema (sewage discharge reservoir) and Saco I (aquaculture-use reservoir) were classified as having high alteration. In contrast, Cachoeira II (water supply reservoir) was classified in the category of moderate alteration.

The water was predominantly well oxygenated, even all reservoirs presenting different usages (Table I). However, the lowest dissolved oxygen value was observed for the reservoir used for aquaculture $\left(0.4 \mathrm{mg} \mathrm{L}^{-1}\right)$. The chlorophyll $a$ concentration was higher for the sewage discharge reservoir $\left(495.6 \pm 289.4 \mu \mathrm{g} \mathrm{L}^{-1}\right)$ and for that used for aquaculture $\left(426.7 \pm 170 \mu \mathrm{g} \mathrm{L}^{-1}\right)$. The one used for water supply had values lower than $100 \mu \mathrm{g} \mathrm{L}^{-1}$ (Table I).

The concentration of phosphorus was also higher for the reservoir receiving sewage discharge as well as for the one used for aquaculture (KruskalWallis; $\mathrm{p}<0.05)$. Although the total nitrogen was not significantly different between the reservoirs (Kruskal-Wallis; $\mathrm{p}<0.05$ ), the reservoir used for aquaculture showed the highest values. In addition, this reservoir showed ammonia $\left(\mathrm{NH}_{3}\right)$ as the greatest contributor to the total nitrogen (63.1 a $98.9 \%$ ), while the reservoir used for water supply presented nitrate $\left(\mathrm{NO}_{3}^{-}\right)$as the highest contribution (29.4-87.5\%) (Table I).

According to Carlson's index, modified by Toledo Júnior (1990), the reservoirs used for aquaculture and the reservoir receiving sewage discharge were classified as hypereutrophic (IET > 80 ), while the reservoir used for water supply was classified as eutrophic (IET < 73) (Table II).

Regarding the precipitation in the region of the reservoirs, the dry season is historically characterized by a low rainfall mean $(<20 \mathrm{~mm})$. However, about 60 days before the sampling campaign in September 2015 (station dry), precipitation was registered above the historical average $(40 \mathrm{~mm})$. For the rainy season, 30 days prior to sampling, $19.4 \mathrm{~mm}$ of rainfall was recorded, being below the historical average ( $>100$ $\mathrm{mm}$ ) (Fig. 2). Due to this, the reservoirs in the rainy season had a similar or lower volume in relation to the dry season.

\section{ALPHA (RICHNESS) AND BETA (COMPOSITION) DIVERSITIES OF MICROCRUSTACEANS}

Seventeen species were recorded, in which 13 were cladocerans and four copepods. The cladocerans were distributed in five families (Sididae, Moinidae, Daphniidae, Macrothricidae and Chydoridae). In contrast, the families Diaptomidae and Cyclopidae were the only ones present among the copepods. The cladoceran species Moina micrura Kurz, 1874 (66.7\%) and Diaphanosoma spinulosum Herbst, 1975 (59.7\%) were the most frequent species in all studied reservoirs. As for copepods, Thermocyclops decipiens Kiefer, 1929 was the most frequent (54.2\%) (Fig. 3) (Table III).

Although there was no significant difference between the reservoir zones in terms of richness (Kruskal-Wallis; $p>0.05$ ), the littoral region of the 
TABLE I

General characterization of the studied reservoirs from the tropical semiarid basin (Pajeú river). Note: Depth refers to the maximum values recorded in the study and not to the maximum overall depth in each reservoir. WSR $=$ water supply reservoir (Cachoeira II); SDR = sewage discharge reservoir (Borborema); AUR = aquaculture-use reservoir (Saco I); Z1 = river zone; $\mathbf{Z 2}=$ transition zone; $\mathbf{Z 3}=$ lacustrine zone. (mean \pm standard deviation) and range (minimum $\%-$ maximum \%).

\begin{tabular}{|c|c|c|c|c|}
\hline General characterization & & WSR & SDR & AUR \\
\hline \multirow{3}{*}{ Maximum depth (m) } & $\mathrm{Z1}$ & 2.5 & 1.1 & 0.8 \\
\hline & $\mathrm{Z} 2$ & 6.5 & 1.7 & 2.8 \\
\hline & $\mathrm{Z3}$ & 14 & 2.1 & 3.2 \\
\hline \multirow{3}{*}{ Dissolved oxygen $\left(\mathrm{mg} \mathrm{L}^{-1}\right)$} & $\mathrm{Z1}$ & $6.6 \pm 1.4$ & $13.1 \pm 5.0$ & $9.2 \pm 3.9$ \\
\hline & $\mathrm{Z} 2$ & $7.4 \pm 1.2$ & $12.5 \pm 2.9$ & $12.5 \pm 1.9$ \\
\hline & $\mathrm{Z3}$ & $7.7 \pm 2.1$ & $11.7 \pm 2.3$ & $12.8 \pm 3.6$ \\
\hline \multirow{3}{*}{ Nitrate $\left(\mathrm{NO}_{3}^{-}\right)(\%)$} & $\mathrm{Z1}$ & $32.4-32.6$ & $11.7-19.4$ & $0.6-1.9$ \\
\hline & $\mathrm{Z} 2$ & $71-81$ & $12.1-13$ & $4.3-10.9$ \\
\hline & $\mathrm{Z3}$ & $29.4-87.5$ & $5.3-10$ & $1.0-24.8$ \\
\hline \multirow{3}{*}{ Nitrite $\left(\mathrm{NO}_{2}^{-}\right)(\%)$} & $\mathrm{Z1}$ & $8.2-22$ & $6.7-10$ & $0.6-1.5$ \\
\hline & $\mathrm{Z} 2$ & $3.4-5.5$ & $6.3-12$ & $0.6-4.9$ \\
\hline & $\mathrm{Z3}$ & $4.1-5.2$ & $4-8.5$ & $0.3-12.1$ \\
\hline \multirow{3}{*}{ Ammonia $\left(\mathrm{NH}_{3}\right)(\%)$} & $\mathrm{Z1}$ & $45.6-59.3$ & $73.9-78.3$ & 96.9-98.9 \\
\hline & $\mathrm{Z} 2$ & $15.6-23.5$ & $75.9-80.7$ & $84.2-95.1$ \\
\hline & $\mathrm{Z3}$ & $8.5-65.4$ & $86-86.2$ & $63.1-98.7$ \\
\hline \multirow{3}{*}{ Total nitrogen $\left(\mu \mathrm{g} \mathrm{L}^{-1}\right)$} & $\mathrm{Z1}$ & $193.9 \pm 167.9$ & $70.6 \pm 48.9$ & $585 \pm 493.3$ \\
\hline & $\mathrm{Z} 2$ & $202.8 \pm 164.4$ & $55.3 \pm 247.7$ & $130.8 \pm 573.7$ \\
\hline & $\mathrm{Z3}$ & $156.9 \pm 164.4$ & $228 \pm 247.7$ & $432.9 \pm 573.7$ \\
\hline
\end{tabular}

\section{TABLE II}

Index of the trophic state, regarding the values of chlorophyll $a$ and total phosphorus, in a tropical semiarid basin (Pajeú river). The classification is based on Carlson (1977) modified by Toledo Júnior (1990). (mean \pm standard deviation). WSR = water supply reservoir (Cachoeira II), SDR = sewage discharge reservoir (Borborema) and AUR = aquaculture-use reservoir (Saco I).

\begin{tabular}{|c|c|c|c|c|c|c|}
\hline \multirow{2}{*}{$\begin{array}{c}\text { Reservoirs } \\
\text { Seasonal period }\end{array}$} & \multicolumn{2}{|c|}{ WSR } & \multicolumn{2}{|c|}{ SDR } & \multicolumn{2}{|c|}{ AUR } \\
\hline & Dry & Rainy & Dry & Rainy & Dry & Rainy \\
\hline Chlorophyll $a$ & $23 \pm 12.1$ & $79.9 \pm 155.6$ & $307.3 \pm 80.7$ & $683.9 \pm 302$ & $266 \pm 68.1$ & $533.8 \pm 125.2$ \\
\hline Total phosphorus & $148.5 \pm 108.2$ & $166.5 \pm 34.3$ & $341.6 \pm 13.2$ & $1109 \pm 43.1$ & $301.3 \pm 20.4$ & $654.9 \pm 52$ \\
\hline Index & 65.3 & 72.1 & 84.4 & 96.9 & 82.9 & 91.9 \\
\hline Classification & \multicolumn{2}{|c|}{ Eutrophic } & \multicolumn{2}{|c|}{ Hypereutrophic } & \multicolumn{2}{|c|}{ Hypereutrophic } \\
\hline
\end{tabular}




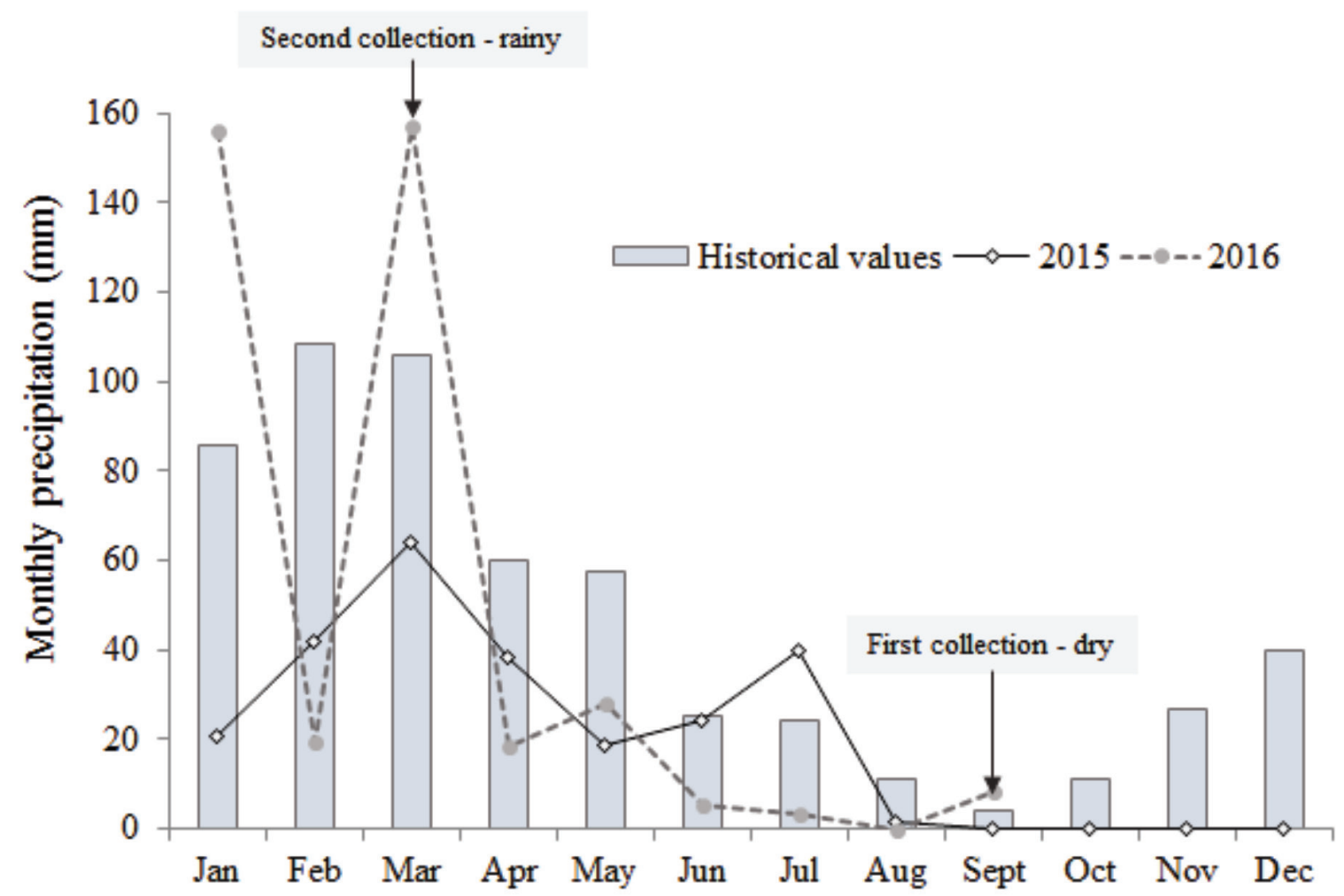

Figure 2 - Historical rainfall mean of the last 10 years and during the study period, with emphasis on the sampling months, in the three reservoirs in a tropical semiarid basin (Pajeú river).

reservoir used for water supply, especially in the riverine zone with its extensive banks of aquatic macrophytes, showed greater microcrustacean richness (15). The other reservoirs had less than 8 species (Table III). In the second campaign (rainy season), no cladocerans were recorded in the aquaculture reservoir.

The sewage discharge reservoir and that used for aquaculture showed higher richness in the dry season (Mann-Whitney; $\mathrm{p}<0.05$ ), whereas that used for the water supply did not present a significant difference between the seasonal periods, showing a homogenous pattern during the time. Although the alpha diversity of copepods was the same for the reservoirs used for water supply and aquaculture (three for each), the beta diversity was different. Some species were exclusively sampled in certain seasonal periods (Table III). In fact, according to the rarefaction curve, the three environments studied showed different richness, being greater for reservoir used to supply (KruskalWallis; $\mathrm{p}<0.05$ ) (Fig. 4).

The composition of cladocerans and copepods are also different among the three reservoirs studied $(F=65.6 ; p=0.001)$ (Fig. 5). The analyzis of SIMPER (percentage of similarity) demonstrated that the main species responsible for similarity between the reservoirs were: $T$. decipiens (77\%), $N$. iheringi (73\%), M. micrura (64\%) and D. spinulosum $(54 \%)$.

\section{DISCUSSION}

The alpha diversity of microcrustaceans recorded in the present study can be considered similar or superior to that observed in other reservoirs of the Neotropical semiarid (Melo-Júnior et al. 2007, Almeida et al. 2009, Simões and Sonoda 2009, 

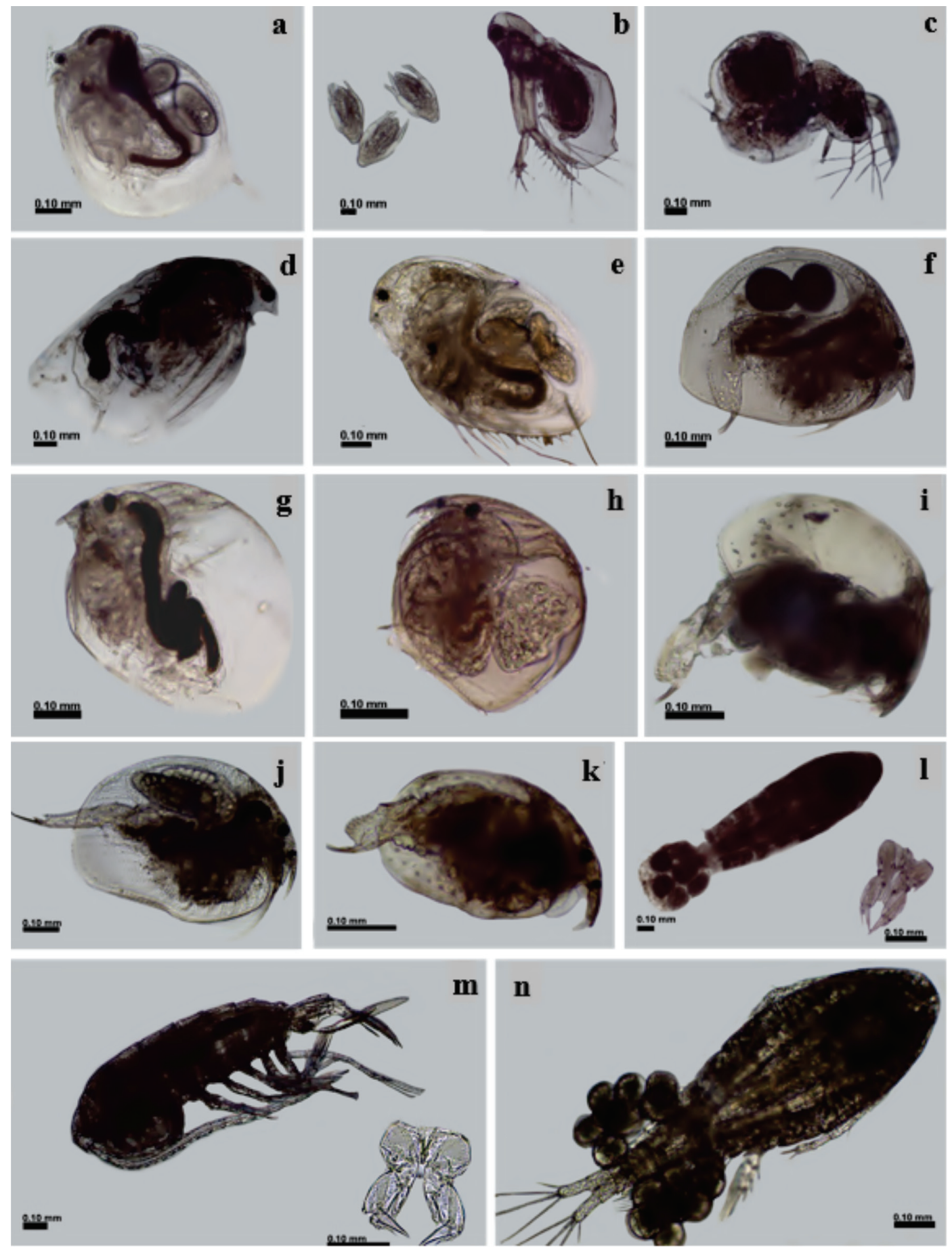

Figure 3 - Microcrustaceans (Cladocera and Copepoda) recorded in the three reservoirs in a tropical semiarid basin (Pajeú river). a, Ceriodaphnia cornuta Sars, 1886; b, Diaphanosoma spinulosum Herbst, 1967; c, Moina micrura Kurz, 1874; d, Simocephalus latirostris Stingelin, 1906; e, Macrothrix elegans Sars, 1901; f, Leberis davidi (Richard, 1895); g, Dunhevedia odontoplax Sars, 1901; h, Ephemeroporus hybridus (Daday, 1905); i, Karualona muelleri (Richard, 1897); j, Kurzia polyspina Hudec, 2000; k, Anthalona verrucosa (Sars, 1901); 1, Notodiaptomus cearensis (Wright, 1936) - with detail of the fifth leg; m, Notodiaptomus iheringi (Wright, 1935) - with detail of the fifth leg; n, Thermocyclops decipiens (Kiefer, 1929). 
TABLE III

List of species of microcrustaceans (Cladocera and Copepoda) registered in the three reservoirs studied, in a tropical semiarid basin (Pajeú river). WSR = water supply reservoir (Cachoeira II), SDR = sewage discharge reservoir (Borborema) and AUR = aquaculture-use reservoir (Saco I).

\begin{tabular}{|c|c|c|c|c|c|c|c|}
\hline & & \multicolumn{2}{|c|}{ WSR } & \multicolumn{2}{|c|}{ SDR } & \multicolumn{2}{|c|}{ AUR } \\
\hline & & Dry & Rainy & Dry & Rainy & Dry & Rainy \\
\hline \multicolumn{8}{|l|}{ CLADOCERA } \\
\hline Sididae & Diaphanosoma spinulosum (Herbst, 1967) & $*$ & * & * & & $*$ & \\
\hline Moinidae & Moina micrura (Kurz, 1874) & * & * & $*$ & * & * & \\
\hline \multirow[t]{2}{*}{ Daphniidae } & Ceriodaphnia cornuta (Sars, 1886) & $*$ & $*$ & & & & \\
\hline & Simocephalus latirostris (Stingelin, 1906) & $*$ & $*$ & & & & \\
\hline Macrothricidae & Macrothrix elegans (Sars, 1901) & $*$ & $*$ & & & & \\
\hline \multirow[t]{8}{*}{ Chydoridae } & Alona ossiani (Sinev, 1998) & $*$ & $*$ & & & & \\
\hline & Anthalona verrucosa (Sars, 1901) & $*$ & $*$ & $*$ & & & \\
\hline & Dunhevedia odontoplax (Sars, 1901) & $*$ & & & & & \\
\hline & Ephemeroporus hybridus (Daday, 1905) & $*$ & $*$ & & & & \\
\hline & Karualona muelleri (Richard, 1897) & $*$ & $*$ & & & $*$ & \\
\hline & Kurzia polyspina (Hudec, 2000) & & $*$ & & & & \\
\hline & Leberis davidi (Richard, 1895) & * & $*$ & & & $*$ & \\
\hline & Leydigia ipojucae (Brehm, 1938) & & & & & $*$ & \\
\hline \multicolumn{8}{|l|}{ COPEPODA } \\
\hline \multirow[t]{2}{*}{ Diaptomidae } & Notodiaptomus cearensis (Wright, 1936) & & $*$ & & $*$ & $*$ & \\
\hline & Notodiaptomus iheringi (Wright, 1935) & $*$ & & & & & $*$ \\
\hline \multirow[t]{4}{*}{ Cyclopidae } & Mesocyclops ellipticus (Kiefer, 1936) & * & * & & & & \\
\hline & Thermocyclops decipiens (Kiefer, 1929) & & & * & $*$ & $*$ & * \\
\hline & Richness & 13 & 13 & 4 & 3 & 7 & 2 \\
\hline & Total richness & & 5 & & 5 & & 8 \\
\hline
\end{tabular}

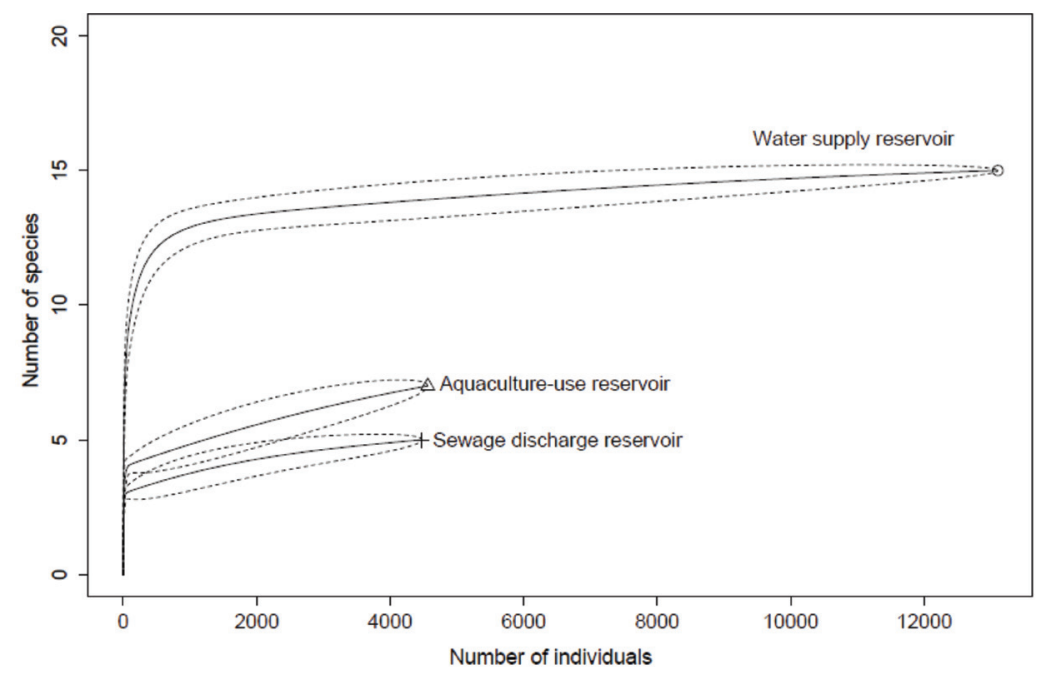

Figure 4 - Rarefaction curve based on the abundance of microcrustaceans in the three reservoirs in a tropical semiarid basin (Pajeú river). 
Brito et al. 2014, Melo et al. 2014). However, about twice the number of cladocerans (22) can be found in a single temporarily shallow pond of the Caatinga in Pernambuco (near the studied reservoirs), which presents an extensive bank of aquatic macrophytes (Diniz et al. 2013). The studied environments did not present aquatic macrophytes throughout every reservoir. This may explain the low richness of microcrustaceans associated to anthropogenic impacts. According to Choi et al. (2014), macrophytes are the main components responsible for heterogeneity in lentic ecosystems, leading to an increase in the number of taxa.

The alpha and beta diversity of the planktonic microcrustaceans did not show a significant difference between the zones of each one of the reservoirs, which demonstrates that the community distribution was homogeneous in the studied environments. This may be related to the fact that the reservoirs studied had a high water residence time. In reservoirs with these characteristics, the longitudinal zonation (river zone, transition zone and lacustrine zone) may be absent, resulting in a similar community composition throughout every reservoir (Naselli-Flores and Barone 2003). In contrast, regarding a pond in Goiás State (Central Brazil), which has little water residence time (30 days), Takahashi et al. (2005) studied the longitudinal variation according to the alpha diversity of cladocerans in this pond and observed significant differences between each reservoir zone, in which the highest was for the transition zone.

In the rainy-season campaign of the present study, particularly in the reservoir used for aquaculture, no species of cladocerans were recorded. This may be related to the bloom of Cylindrospermopsis raciborskii recorded in this reservoir during the period of study (M.C.P. Vilar, personal communication). This cyanobacterium is considered potentially toxic to zooplankton, especially to cladocerans (Ferrão-Filho et al. 2014). The presence of these potentially toxic cyanobacteria is a common feature in Brazilian Northeast Reservoirs (Dantas et al. 2011, Almeida et al. 2012). In addition, this reservoir was the one with the lowest dissolved oxygen value $(0.4 \mathrm{mg}$ $\mathrm{L}^{-1}$ ). These reductions in oxygen levels may be related to algae blooms in this reservoir and may be responsible for the death of several members of the aquatic community or even the reduction in species richness (Chorus and Bartram 1999).

This reservoir and the one with sewage and solid waste disposal showed greater alpha diversity in the dry season, which points to the fact that in the rainy season the reservoirs had a similar or lower volume than the one recorded in the dry season at some sampling areas. According to ArangurenRiaño et al. (2011), a reduction in the water volume tends to reduce the species richness.

The three reservoirs studied presented different richness of species, being higher for the reservoir used for water supply (deeper reservoir). Although all the reservoirs are considered eutrophic, those with aquaculture-use and receiving sewage have much more significantly anthropogenic changes. This fact may explain the low richness found, and also these two reservoirs presented the highest concentrations of phosphorus and reduced or even absent banks of aquatic macrophytes.

It was detected that though the reservoirs are eutrophic, close to each other and located in a same basin, it supports a beta diversity of cladocerans and copepods that is different between the reservoirs, accepting the hypothesis of the study. Due to the different usages, the reservoirs showed different nitrogen sources (Boyer et al. 2002), resulting in probable distinct responses in the composition of the main food (phytoplankton) and, consequently, zooplankton (Burford and Pearson 1998, Hunt and Matveev 2005, Bozelli et al. 2009). Ammonia, for example, which is predominant in the highly altered reservoirs (Borborema and Saco I), is easily assimilated by phytoplankton. Thus, when present in higher concentrations it makes the growth of 


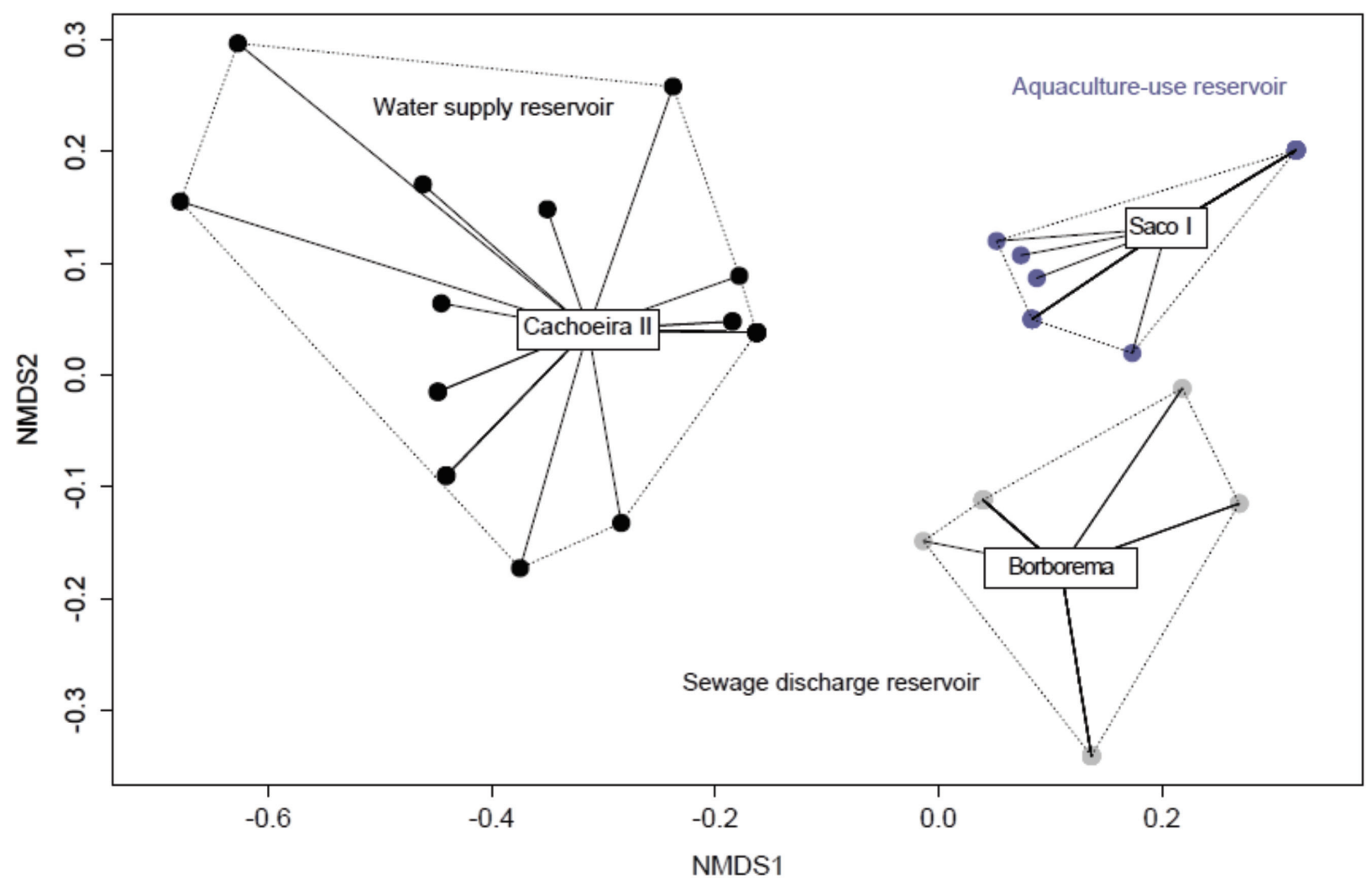

Figure 5 - Non-metric multidimensional scaling with the data of the cladoceran and copepod composition from three reservoirs in a tropical semiarid basin (Pajeú river).

cyanobacteria easier and the development of bloom faster (Rückert and Giani 2004). In addition, the reservoir used for aquaculture (Saco I) receives other kinds of nutrients for fish farming. Therefore, the concentration of ammonia is higher in this reservoir (Pereira and Mercante 2005), resulting in stress for all aquatic biota.

Although the studied reservoirs were eutrophic, they also showed similarities in the physico-chemical conditions throughout their entire areas. This promoted more homogenous communities in these reservoirs, which did not present any difference between each of their zones. However, even though they are located less than 3 $\mathrm{km}$ from each other, the alpha and beta diversities of the microcrustaceans are different between the reservoirs. This may be a response to the variety of usage and of nitrogen sources in the studied ecosystems. The reservoirs receiving sewage and solid waste and used for aquaculture are highly modified, sharing several species compared to the reservoir used for water supply, which has moderate changes and shows a greater number of exclusive taxa. As the greatest alpha diversity was verified for the reservoir with smaller impacts this indicates that the diversity can be used as indicator of the environmental quality.

\section{ACKNOWLEDGMENTS}

We acknowledge the Fundação de Amparo à Ciência e Tecnologia do Estado de Pernambuco (FACEPE), for the first author's Master's scholarship (\#IBPG0996-2.05/14), and the Universidade Federal Rural de Pernambuco (UFRPE), for the financial support for this research, through the funds of the Universal Rural Announcement (2014). We also wish to thank Wesley Patrício de Sá Cordeiro for the 
identification of the aquatic macrophytes, as well as Elton José França for the assistance throughout the whole fieldwork, and to Thiago Gonçalves Souza, for help with the analyzes in program $\mathrm{R}$.

\section{REFERENCES}

ALMEIDA VLS, DANTAS ÊW, MELO-JÚNIOR M, BITTENCOURT-OLIVEIRA MC AND MOURA AN. 2009. Zooplanktonic community of six reservoirs in northeast Brazil. Braz J Biol 69: 57-65.

ALMEIDA VLS, MELÃO MGG AND MOURA AN. 2012. Plankton diversity and limnological characterization in two shallow tropical urban reservoirs of Pernambuco State, Brazil. An Acad Bras Cienc 84: 537-550.

APAC - AGÊNCIA PERNAMBUCANA DE ÁGUAS E CLIMA. 2016. URL: <http://www.apac.pe.gov.br/pagina. php?page_id $=5>$.

ARANGUREN-RIAÑO N, GUISANDE C AND OSPINA R. 2011. Factors controlling crustacean zooplankton species richness in Neotropical lakes. J Plankton Res 33: 1295-1303.

ARRUDA GA, DINIZ LP, ALMEIDA VLS, NEUMANNLEITÃO S AND MELO-JÚNIOR M. 2017. Rotifer community structure in fish-farming systems associated with a Neotropical semiarid reservoir in Northeastern Brazil. Aquacult Res 48: 4910-4922.

BOUVY M, PAGANO M AND TROUSSELLIER M. 2001. Effects of a cyanobacterial bloom (Cylindrospermopsis raciborskii) on bacteria and zooplankton communities in Ingazeira Reservoir (Northeast Brazil). Aquat Microb Ecol 25: $215-227$.

BOXSHALL GA AND DEFAYE D. 2008. Global diversity of copepods (Crustacea: Copepoda) in freshwater. Hydrobiology 595: 195-207.

BOYER EW, GOODALE CL, JAWORSKI NA AND HOWARTH R. 2002. Anthropogenic nitrogen sources and relationships to riverine nitrogen export in the northeastern U.S.A. Biogeochemistry 57: 137-169.

BOZELLI RL ET AL. 2009. Interactive effects of environmental variability and human impacts on the longterm dynamics of an Amazonian floodplain lake and a South Atlantic coastal lagoon. Limnologica 39: 306-313.

BRITO MTS, DINIZ LP AND MELO-JÚNIOR M. 2014. Fauna planctônica de cinco lagos artificiais da bacia do Riacho do Pontal, sertão de Pernambuco. Rev Nordestina Zool 8: 35-51.

BRITO MTS, NASCIMENTO FILHO SL, VIANA GFS AND MELO-JÚNIOR M. 2016. Aplicação de um protocolo de avaliação ambiental rápida em dois reservatórios do semiárido. Braz J Aquat Sci Technol 20: 1-5.
BURFORD MA AND PEARSON DC. 1998. Effect of different nitrogen sources on phytoplankton composition in aquaculture ponds. Aquat Microb Ecol 15: 277-284.

CARLSON RE. 1977. A trophic state index for lakes. Limmol Oceanogr 22: 361-380.

CHOI JY, JEONG KS, KIM SK, LA GH, CHANG KH AND JOO G-J. 2014. Role of macrophytes as microhabitats for zooplankton community in lentic freshwater ecosystems of South Korea. Ecol Inform 24: 177-185.

CHORUS I AND BARTRAM J. 1999. Toxic cyanobacteria in water - A guide to their public health consequences. E and FN Spon, London, England.

COSTA DF, BARBOSA JEL AND DANTAS EW. 2016. Productivity-diversity relationships in reservoir phytoplankton communities in the semi-arid region of northeastern Brazil. J Arid Environ 129: 64-70.

DANTAS EW, MOURA AN AND BITTENCOURTOLIVEIRA MC. 2011. Cyanobacterial blooms in stratified and destratified eutrophic reservoirs in semi-arid region of Brazil. An Acad Bras Cienc 83: 1327-1338.

DINIZ LP, ELMOOR-LOUREIRO LMA, ALMEIDA VLS AND MELO-JÚNIOR M. 2013. Cladocera (Crustacea, Branchiopoda) of a temporary shallow pond in the Caatinga of Pernambuco, Brazil. Nauplius 21: 65-78.

ELMOOR-LOUREIRO LMA. 1997. Manual de identificação de cladóceros límnicos do Brasil. Brasília: Universa, 155 p.

ELMOOR-LOUREIRO LMA. 2000. Brazilian cladocera studies: where do we stand? Nauplius 8: 117-131.

FERRÃO-FILHO AS, SOARES MC, LIMA RS AND MAGALHÃES VF. 2014. Effects of Cylindrospermopsis raciborskii (cyanobacteria) on the swimming behavior of Daphnia (cladocera). Environ Toxicol Chem 33: 223-229.

FORRÓ L, KOROVCHINISKY NM, KOTOV AA AND PETRUSEK A. 2008. Global diversity of cladocerans (Cladocera; Crustacea) in freshwater. Hydrobiology 595: 177-184.

GAZONATO-NETO AJ, SILVA LC, SAGGIO AA AND ROCHA O. 2014. Zooplankton communities as eutrophication bioindicators in tropical reservoirs. Biota Neotrop 14: 1-12.

HAVEL JE, SHURIN JB AND JONES J. 2002. Estimating dispersal from patterns of spread: spatial and local controlo of lake invasions. Ecology 83: 3306-3318.

HUBBELL SP. 2001. The Unified Neutral Theory of Biodiversity and Biogeography. Princeton, NJ: Princeton University Press, 392 p.

HUNT RJ AND MATVEEV VF. 2005. The effects of nutrients and zooplankton community structure on phytoplankton growth in a subtropical Australian reservoir: an enclosure study. Limnologica 35: 90-101. 
KOROLEFF F. 1976. Determination of nutrients. In: Grasshoff K (Ed), Methods of seawater analysis, Verlag Chemie, Weinhein, p. 117-187.

LOPES PM, BINI LM, DECLERCK SAJ, FARJALLA VF, VIEIRA LCG, BONECKER CC, LANSAC-TOHA FA, ESTEVES FA AND BOZELLI RL. 2014. Correlates of Zooplankton Beta Diversity in Tropical Lake Systems. PLoS ONE 9: 1-8.

MACKERETH FJH, HERON J AND TALLING JF. 1978. Water analysis: some revised methods for limnologists. Scientific Publications, London, 120 p.

MATSUMURA-TUNDISI T. 1986. Latitudinal distribution of Calanoida copepods in freshwater aquatic systems of Brazil. Rev Bras Biol 43: 527-553.

MELO AS, SCHNECK F, HEPP LU, SIMÕES NR, SIQUEIRA T AND BINI LM. 2011. Focusing on variation: methods and applications of the concept of beta diversity in aquatic ecosystems. Acta Limnol Bras 23: 318-331.

MELO-JÚNIOR M, ALMEIDA VLS, PARANAGUÁ MN AND MOURA NA. 2007. Crustáceos planctônicos de um reservatório oligotrófico no nordeste do Brasil. Rev Bras Zoociências 9: 19-30.

MELO TX, LOURENÇO LJS AND MEDEIROS ESF. 2014. Checklist of zooplankton from the upper Ipanema River (Pernambuco), an intermittent river in semi-arid Brazil. Check List 10: 524-528.

NASELLI-FLORES LAND BARONE R. 2003. Steady-state assemblages in a Mediterranean hypertrophic reservoir. The role of Microcystis ecomorphological variability in maintaining an apparent equilibrium. Hydrobiologia 502: 133-143.

OKSANEN J ET AL. 2016. Vegan: Community Ecology Package.

PERBICHE-NEVES G, BOXSHALLGA,PREVIATTELLI D, NOGUEIRA MG AND ROCHA CEF. 2015. Identification guide to some Diaptomid species (Crustacea, Copepoda, Calanoida, Diaptomidae) of "de la Plata" River Basin (South America). ZooKeys 497: 1-111.

PEREIRA L AND MERCANTE CTJ. 2005. A amônia nos sistemas de criação de peixes e seus efeitos sobre a qualidade da água. Bol Inst Pesca 31: 81-88.

R DEVELOPMENT CORE TEAM. 2015. R: A language and environment for statistical computing. R Foundation for Statistical Computing, Vienna, Austria. URL: $<$ http:// www.R-project.org/>.

REID JW. 1985. Chave de identificação e lista de referências bibliográficas para espécies continentais sul-americanas de vida livre da ordem Cyclopoida (Crustacea, Copepoda). Bol Zoologia 9: 17-143.

RÜCKERT GV AND GIANI A. 2004. Effect of nitrate and ammonium on the growth and protein concentration of Microcystis viridis Lemmermann (Cyanobacteria). Rev Bras Bot 27: 325-331.

SILVA WM. 2008. Diversity and distribution of the freeliving freshwater Cyclopoida (Copepoda: Crustacea) in the Neotropics. Braz J Biol 68: 1099-1106.

SIMÕES NR AND SONODA SL. 2009. Estrutura da assembléia de microcrustáceos (Cladocera e Copepoda) em um reservatório do semi-árido Neotropical, Barragem de Pedra, Estado da Bahia, Brasil. Acta Sci Biol Sci 31: 89-95.

SOARES CEA AND ELMOOR-LOUREIRO LMA. 2011. Uma atualização da lista de Cladocera Cladocera (Crustacea, Branchiopoda) do Estado de Pernambuco, Brasil. Biota Neotropica 11: 1-6.

SOUSA FDR, ELMOOR-LOUREIRO LMA AND SANTOS S. 2015a. Redescription of Coronatella poppei (Richard, 1897) (Crustacea, Branchiopoda, Chydoridae) and a revision of the genus in Brazil, with description of new taxa. Zootaxa 3955: 211-244.

SOUSA FDR, SANDRO S, GÜNTZEL AM, DINIZ LP, MELO-JÚNIOR M AND ELMOOR-LOUREIRO LMA. 2015b. Description of a new species of the costatagroup (Cladocera, Chydoridae, Aloninae) from Brazil. Zootaxa 4040: 445-457.

STRA ̌́KRABA M AND TUNDISI JG. 1999. Reservoir ecosystem functioning: theory and application. In: Tundisi JG and Straškraba M (Eds), Theoretical Reservoir ecology and its applications. São Carlos: International Institute of Ecology/Brazilian Academy of Sciences, p. 565-583.

STRICKLAND JDH AND PARSONS TR. 1960. A manual of seawater analysis. B Fish Res Board Can 125: 1-185.

TAKAHASHI EM, LANSAC-TÔHA FA, VELHO LFM AND BONECKER CC. 2005. Longitudinal distribution of cladocerans (Crustacea) in a Brazilian tropical reservoir. Acta Limnol Bras 17: 257-265.

TOLEDO JÚNIOR AP. 1990. Informe preliminar sobre os estudos para obtenção de um índice para avaliação simplificada do estado trófico de reservatórios de regiões quentes tropicais. Relatório técnico. CETESB, São Paulo, $11 \mathrm{p}$.

YANG XE, WU X, HAO HLAND HE ZL. 2008. Mechanisms and assessment of water eutrophication. J Zhejiang Univ Sci B 9: 197-209.

WETZEL RG. 1993. Limnologia. Lisboa: Fundação Calouste Gulbenkian, 919 p. 